\title{
The Atypical Ribosomal RNA Complement of Rhodopseudomonas spheroides
}

\author{
BY T. G. LESSIE* \\ Microbiology Unit, Department of Biochemistry, University of Oxford
}

(Received 28 September 1964)

\begin{abstract}
SUMMARY
Ribosomes and phenol-purified RNA were prepared from Rhodopseudomonas spheroides and were characterized by sucrose density-gradient centrifugation and sedimentation-velocity centrifugation. The ribosomes extracted from $R$. spheroides correspond to the $30 \mathrm{~S}, 50 \mathrm{~S}$ and $70 \mathrm{~S}$ ribosomes derived from other bacteria. Under appropriate conditions polyribosomes were extracted. The primary ribosomal RNA of $R$. spheroides corresponds to the $16 \mathrm{~S}$ particle of other bacteria. Rhodopseudomonas spheroides was devoid of the 23S ribosomal RNA typically found in other bacteria. Preparations of phenol-purified $R$. spheroides RNA contain, in addition to $16 \mathrm{~S}$ RNA, smaller amounts of an RNA component which sediments more slowly than the 16S unit, with a sedimentation coefficient of about 1415S. Of several other Athiorhodaceae examined, only Rhodopseudomonas capsulata had an unusual RNA complement like that of $R$. spheroides.
\end{abstract}

\section{INTRODUCTION}

The ribosomal RNA isolated from bacteria consists typically of components with sedimentation coefficients of $16 \mathrm{~S}$ and $23 \mathrm{~S}$. In Escherichia coli the $16 \mathrm{~S}$ particle derives both from $30 \mathrm{~S}$ and $50 \mathrm{~S}$ ribosomes; the $23 \mathrm{~S}$ particle derives only from $50 \mathrm{~S}$ ribosomes (Kurland, 1960). The 30S and 50S ribosomes aggregate in appropriate magnesium concentrations to form $70 \mathrm{~S}$ ribosomes which function in protein synthesis.

The studies of Aronson \& McCarthy (1961) have suggested that $16 \mathrm{~S}$ and $23 \mathrm{~S}$ ribosomal RNAs are built from multiples of a single subunit, the 23S particle being viewed as a dimer of $16 \mathrm{~S}$ RNA. This view is supported by the work of Spahr \& Tissieres (1959), which showed that the 30S and $50 \mathrm{~S}$ ribosomes of Escherichia coli had similar nucleotide compositions, and the work of Petermann \& Pavlovec (1963), which indicated that there was interconversion between the $18 \mathrm{~S}$ and $28 \mathrm{~S}$ RNA particles of rat liver ribosomes. On the other hand, Aronson (1962, 1963) showed for several bacteria that the RNAs from $30 \mathrm{~S}$ and $50 \mathrm{~S}$ ribosomes differed in base sequence. Yankofsky \& Spiegelman (1963) reported that $16 \mathrm{~S}$ and $23 \mathrm{~S}$ ribosomal RNAs hybridized with different sites on the bacterial genome. These observations imply that $16 \mathrm{~S}$ and $23 \mathrm{~S}$ RNA particles are distinct units. The results reported in the present work show that Rhodopseudomonas spheroides contains a usual complement

* Present address: Department of Biological Sciences, Purdue University, Lafayette, Indiana. 
of ribosomes although it has only one of the usual ribosomal RNA particles, namely that corresponding to the $16 \mathrm{~S}$ ribosomal RNA of $E$. coli. This suggests that ribosomes can be built up from the $16 \mathrm{~S}$ unit.

\section{METHODS}

Organisms. The strains of Rhodopseudomonas spheroides studied were: strain L (NCIB 8253); strain L-81, which was derived from strain $\mathrm{L}$ and does not form photopigments; strain Ga, a spontaneous green mutant deriving from strain 2.4.1 of Professor C. B. van Niel's collection; strain M-25, which derived from strain 2.4.7 of Professor van Niel's collection, and requires uracil for growth. Strain M-25 does not grow when orotic acid is substituted for uracil; presumably its pyrimidine synthesis is blocked at some step after the formation of orotic acid.

Rhodopseudomonas spheroides strains Ga and M-25 were obtained from Professor W. R. Sistrom. All other bacteria were obtained from the collection of Dr June Lascelles. Other Athiorhodaceae used were: Rhodospirillum rubrum (NCIB 8255); Rhodopseudomonas palustris, 2.1.7; Rhodopseudomonas gelatinosa, 2.2.13; Rhodopseudomonas capsulata, 2.3.11. The last three organisms were originally from Professor van Niel's collection.

The Escherichia coli used was laboratory strain 88.

Growth of organisms. All the bacteria were grown to a concentration equivalent to about $100 \mu \mathrm{g}$. protein $/ \mathrm{ml}$. in the glutamate medium of Lascelles (1959) with succinate substituted for malate (medium SG). For growth of $\boldsymbol{R}$. spheroides strain $\mathrm{M}-\mathbf{2 5}$, the medium was supplemented with uracil (5 $\mu \mathrm{g} . / \mathrm{ml}$.$) .$

Escherichia coli was grown aerobically in Erlenmeyer flasks containing volumes of media equal to $1 / 10$ their nominal capacities. The cultures were shaken at $30^{\circ}$ on a reciprocal shaker. Aerobic cultures of $\boldsymbol{R}$. spheroides were grown under the same conditions.

Anaerobic cultures of Athiorhodaceae were incubated at $34^{\circ}$ in flat medicine bottles or Roux bottles filled to capacity, and were illuminated at the surface of a water bath with a light intensity of about $1200 \mathrm{ft}$.-c. The cultures were aerated with a gas mixture of $5 \%(\mathrm{v} / \mathrm{v}) \mathrm{CO}_{2}+95 \%(\mathrm{v} / \mathrm{v}) \mathrm{N}_{2}$.

Harvesting of cultures. Organisms were centrifuged, washed in $5 \times 10^{-3} \mathrm{M}$-tris buffer ( $\mathrm{pH} 7 \cdot 4$ ) containing $10^{-2} \mathrm{M}-\mathrm{MgCl}_{2}$, and then frozen.

Radioactive labelling of bacterial RNA. Rhodopseudomonas spheroides strain M-25 or Escherichia coli was grown in SG medium containing per ml. $5 \mu \mathrm{g}$. uracil and $0 \cdot 3 \mu$ c. ${ }^{2-14} \mathrm{C}$ uracil (obtained from the Radiochemical Centre, Amersham, Buckinghamshire). The bacteria were centrifuged, washed three times in $5 \times 10^{-3} \mathrm{M}$-tris buffer $\left(\mathrm{pH} 7 \cdot 4\right.$ ) containing $10^{-2} \mathrm{M}_{-} \mathrm{MgCl}_{2}$, and then frozen.

Estimation of protein and ribonucleic acid. Cell protein was determined by the Folin phenol method (Lowry, Rosebrough, Farn \& Randall, 1951) after digestion of organisms in $\mathrm{N}-\mathrm{NaOH}$ for $2 \mathrm{hr}$ at $40^{\circ}$. RNA was estimated by the orcinol method of Schneider (1945) following extraction from samples with $5 \%(\mathrm{w} / \mathrm{v})$ trichloroacetic acid for $30 \mathrm{~min}$. at $90^{\circ}$.

Preparation of bacterial extracts and phenol-purified $R N A$. Frozen organisms were thawed and suspended to a concentration equivalent to between 6 and $15 \mathrm{mg}$. protein $/ \mathrm{ml}$. in $5 \mathrm{ml}$. of $5 \times 10^{-3} \mathrm{M}$-tris buffer ( $\mathrm{pH} 7 \cdot 4$ ) containing $10^{-2} \mathrm{M}^{-\mathrm{MgCl}_{2}}$ and 
$2 \mu \mathrm{g}$. DNAase/ml. (DNAase from Worthington Biochemical Co., New Jersey, U.S.A.). The suspensions were passed through a cold French press under $6000 \mathrm{lb}$./in. ${ }^{2}$ pressure. The pressed material was incubated for $10 \mathrm{~min}$. at room temperature (about $23^{\circ}$ ) to allow DNA degradation to proceed. All further steps were carried out at $4^{\circ}$. A portion of the pressed material was centrifuged for $10 \mathrm{~min}$. at $10,000 \mathrm{~g}$ to remove unbroken organisms and debris. The supernatant fluid was pipetted off, dialysed overnight against 1000 times its volume of $5 \times 10^{-3} \mathrm{M}$-tris buffer $(\mathrm{pH} \mathrm{7 \cdot 4})$ containing specified amounts of $\mathrm{MgCl}_{2}$, and used as a source of ribosomes. Under these conditions at least $80 \%$ of the bacterial RNA was recovered in the dialysed supernatant fluid.

The portion of the pressed material left uncentrifuged was shaken with $1 / 25$ its volume of sodium laurylsulphate for $10 \mathrm{~min}$. to dissociate protein from RNA, and the solution deproteinized by the phenol method of Schramm \& Gierer (1956). The phenol-purified RNA thus obtained was dialysed overnight against 1000 times its volume of $5 \times 10^{-3} \mathrm{M}$-tris buffer ( $\mathrm{pH} \mathbf{7} \cdot 4$ ) containing specified amounts of $\mathrm{MgCl}_{2}$. Samples of phenol-purified RNA were occasionally frozen before use; this did not alter the sedimentation behaviour of the RNA.

Preparation of polyribosome extracts. Bacteria were suspended to a concentration equivalent to about $50 \mathrm{mg}$. protein $/ \mathrm{ml}$. in $5 \mathrm{ml}$. of $5 \times 10^{-3} \mathrm{M}$-tris buffer $(\mathrm{pH} 7 \cdot 4$ ) containing $2 \times 10^{-3} \mathrm{M}-\mathrm{MgCl}_{2}$ and $2 \mu \mathrm{g}$. DNAase $/ \mathrm{ml}$. The bacterial suspension was passed through a cold French press under a pressure of about $1000 \mathrm{lb}$./in. ${ }^{2}$, and the pressed material was incubated for $10 \mathrm{~min}$. at room temperature to allow DNA degradation to proceed. All further steps were carried out at $4^{\circ}$. The pressed material was centrifuged for $10 \mathrm{~min}$. at $10,000 \mathrm{~g}$. The supernatant fluid was discarded, and the pellet was suspended in $3 \mathrm{ml}$. of $5 \times 10^{-3} \mathrm{M}$-tris buffer $(\mathrm{pH} \mathbf{7} \cdot \mathbf{4}$ ) containing $2 \times 10^{-3} \mathrm{M}-\mathrm{MgCl}_{2}$ and $0.3 \%(\mathrm{w} / \mathrm{v})$ sodium deoxycholate. After incubation for $5 \mathrm{~min}$. to solubilize the RNA, the suspension was centrifuged for $10 \mathrm{~min}$. at $10,000 \mathrm{~g}$. The pellet was discarded, and the supernatant fluid used as a source of polyribosomes. $5-10 \%$ of the bacterial RNA was recovered in the supernatant fluid.

Sucrose gradient centrifugation. Linear sucrose gradients (5 ml.) were prepared in plastic centrifuge tubes appropriate to the SW-39 swinging bucket Spinco rotor by using an apparatus like that described by Britten \& Roberts (1960). Portions $(0.2 \mathrm{ml}$.) of crude bacterial extract or phenol-purified RNA followed by $0.1 \mathrm{ml}$. of sucrose solution (4 or $5 \%$ sucrose for gradients increasing, respectively, from 5 or $15 \%$ sucrose) were drawn into a pipette with a capillary tip. The contents of the pipette were layered on to a sucrose gradient with the same buffer and $\mathrm{Mg}$ composition as the RNA sample, and the tubes were centrifuged for specified times at $38,000 \mathrm{rev} . / \mathrm{min}$. and $4^{\circ}$ in a Spinco model L ultracentrifuge. After centrifugation the tubes were fitted with a stopper attached by tubing to a drawn $10 \mathrm{ml}$. syringe. The bottoms of the plastic tubes were coated externally with silicone grease and punctured with a small-bore syringe needle. Twenty to thirty 5-drop samples were collected from the gradients by gradually closing the syringe. Portions $(0.05 \mathrm{ml}$.) of each sample were assayed for radioactivity (an Isotopes Development Laboratories liquid scintillation counter was used to measure radioactivity). The remaining fractions were diluted with water, and their absorbancy at $260 \mathrm{~m} \mu$ was determined. 
Analytical ultracentrifugation. Samples of phenol-purified RNA prepared in $5 \times 10^{-3} \mathrm{M}$-tris buffer $(\mathrm{pH} \mathbf{7} \cdot 4)$ containing specified amounts of $\mathrm{MgCl}_{2}$ were centrifuged at $20^{\circ}$ in a Spinco model $\mathrm{E}$ ultracentrifuge. An optical cell with a light path of $12 \mathrm{~mm}$. was used. For schlieren optics the RNA concentration was between 1 and $3 \mathrm{mg} . / \mathrm{ml}$., and the bar angle was set between 30 and $60^{\circ}$, depending upon the sensitivity required. For ultraviolet optics the RNA concentration was about $50 \mu \mathrm{g} . / \mathrm{ml}$. The photographic plates obtained from experiments with u.v. optics were analysed by means of a Spinco Analytrol photodensitometer equipped with a microanalyser attachment.

Rhodopseudomonas spheroides RNA, like Escherichia coli RNA, sediments more rapidly the higher the magnesium concentration and the smaller the RNA concentration. Since the experiments did not depend upon precise knowledge of sedimentation coefficients, apparent values have been given without correcting to infinite dilution or taking into account the effect of magnesium concentration.

\section{RESULTS}

\section{Sucrose-gradient centrifugation}

Phenol-purified RNA was prepared from Escherichia coli mixed with aerobically or anaerobically grown Rhodopseudomonas spheroides, and was characterized by sucrose-gradient centrifugation. The $R$. spheroides RNA included RNA corresponding to the 16S RNA particle of $E$. coli and smaller amounts of RNA which sedimented less rapidly than the $16 \mathrm{~S}$ unit, but no RNA corresponding to the $23 \mathrm{~S} E$. coli unit. This is shown in Fig. $1 a$ for a mixture of about $95 \% E$. coli RNA and $5 \%$ ${ }^{14} \mathrm{C}$-uracil-labelled RNA from $R$. spheroides strain $\mathrm{M}-25$, in $10^{-4} \mathrm{M}-\mathrm{MgCl}_{2}$. The results were the same with RNA obtained from ${ }^{14} \mathrm{C}$-uracil-labelled $\boldsymbol{E}$. coli combined with excess $R$. spheroides. This observation rules out the possibility that the absence of $R$. spheroides $23 \mathrm{~S} \mathrm{RNA}$ was due to degradation by ribonuclease. In $10^{-2} \mathrm{M}-\mathrm{MgCl}_{2}$, $R$. spheroides RNA tended to aggregate to form RNA broadly sedimenting throughout the 23S region without a well-defined peak (see Fig. $1 b$ ).

Similar characterization of a mixture of ribosomes from mixtures of Escherichia coli and ${ }^{14} \mathrm{C}$-uracil-labelled Rhodopseudomonas spheroides in $10^{-4} \mathrm{M}^{-} \mathrm{MgCl}_{2}$ indicated that $R$. spheroides had a complement of ribosomes corresponding to the $30 \mathrm{~S}$ and $50 \mathrm{~S}$ ribosomes of $\boldsymbol{E}$. coli (see Fig. $2 a$ ). It should be noted that the $50 \mathrm{~S}$ ribosomes of $\boldsymbol{R}$. spheroides sedimented slightly behind the corresponding $\boldsymbol{E}$. coli ribosomes. In $10^{-2} \mathrm{M}-\mathrm{MgCl}_{2}, R$. spheroides ribosomes aggregated to form a ribosomal RNA particle corresponding to the 70S unit of $\boldsymbol{E}$. coli (see Fig. $2 b$ ). Like the 50S ribosomes, the $\boldsymbol{R}$. spheroides $70 \mathrm{~S}$ ribosomes sedimented behind the corresponding $\boldsymbol{E}$. coli particles. Furthermore, the $\boldsymbol{R}$. spheroides $70 \mathrm{~S}$ ribosomes did not dimerize with the more abundant $E$. coli $70 \mathrm{~S}$ ribosomes to form $100 \mathrm{~S}$ particles.

Ribosomes sedimenting more rapidly than the 70S units were obtained from Rhodopseudomonas spheroides by disrupting the organisms at low pressures in a French press and treating the particulate fraction of the product with sodium deoxycholate to solubilize the RNA particles (see Fig. 3). This class of ribosomes is analogous to the polyribosomal RNA of other investigators (see Schlessinger, 1963). When $R$. spheroides was disrupted at the usual pressures (about $6000 \mathrm{lb}$./in. ${ }^{2}$ ) in $2 \times 10^{-3} \mathrm{M}^{-} \mathrm{MgCl}_{2}$ no ribosomes sedimenting ahead of the $70 \mathrm{~S}$ units were detected 
in either the sodium deoxycholate-treated fraction or the soluble fraction of the pressed material.

\section{Sedimentation-velocity centrifugation}

Ultraviolet optics. Resolution of Rhodopseudomonas spheroides ribosomal RNA by analytical ultracentrifugation and the use of ultraviolet (u.v.) optics confirmed that $\boldsymbol{R}$. spheroides was devoid of the usual $23 \mathrm{~S}$ ribosomal RNA. For example, preparations of phenol-purified RNA from $R$. spheroides strain $\mathbf{G a}$ in $10^{-4} \mathrm{M}-\mathrm{MgCl}_{2}$ appeared to contain a single species of ribosomal RNA (see Fig. 4a). This RNA corresponded

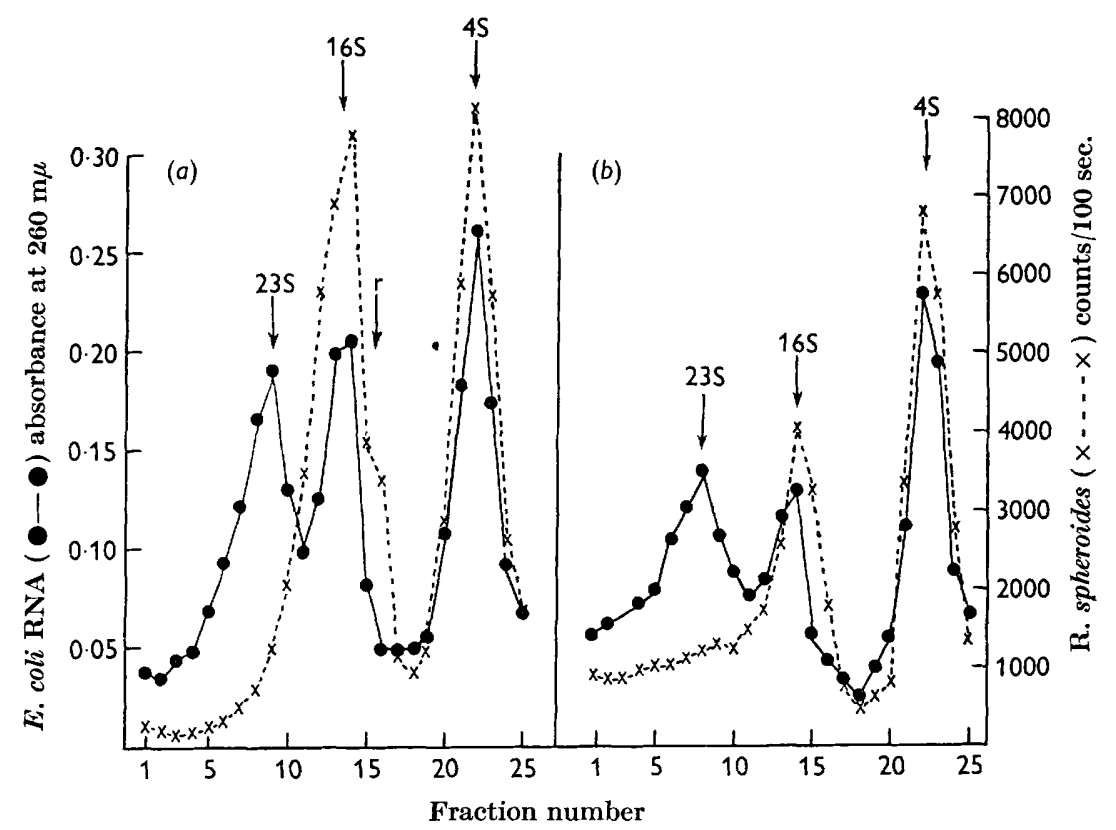

Fig. 1. ${ }^{2-14} \mathrm{C}$-uracil-labelled organisms from $30 \mathrm{ml}$. of an anaerobic Rhodopseudomonas spheroides culture and unlabelled organisms from $300 \mathrm{ml}$. Escherichia coli culture were treated together to obtain a crude ribosome extract (see Methods). A portion of the ribosome extract was further treated to obtain phenol-purified RNA. One sample of the mixture of $E$. coli and $R$. spheroides phenol-purified RNAs was dialysed overnight against tris buffer containing $10^{-4} \mathrm{M}-\mathrm{MgCl}_{2}$; another sample was dialysed against buffer containing $10^{-2} \mathrm{M}^{-\mathrm{MgCl}_{2}}$. Samples $\left(0 \cdot 2 \mathrm{ml}\right.$.) of the $\mathrm{RNA}$ dialysed against $10^{-4} \mathrm{M}-\mathrm{MgCl}_{2}$ (about $600 \mu \mathrm{g}$. RNA) were centrifuged for $5 \mathrm{hr}$ through linear 5-15\% (w/v) sucrose gradient mixtures containing $10^{-4} \mathrm{M}_{-} \mathrm{MgCl}_{2}$ (Fig. $1 \mathrm{a}$ ). Samples $(0.2 \mathrm{ml}$.) of the RNA dialysed against $10^{-2} \mathrm{M}-\mathrm{MgCl}_{2}$ were centrifuged for $4 \mathrm{hr}$ through $5-20 \%(\mathrm{w} / \mathrm{v})$ sucrose gradient solutions containing $10^{-2} \mathrm{M}-\mathrm{MgCl}_{2}$ (Fig $\mathrm{Ib}$ ). Fractions were collected from the gradients. $R$. spheroides RNA (only about $5 \%$ of the RNA applied to the gradients) was assayed by determining radioactivities of the fractions. $E$. coli RNA was determined by measuring absorbance of the same fractions at $260 \mathrm{~m} \mu$.

to the $16 \mathrm{~S}$ unit of Escherichia coli (see Fig. $4 b$ ). At the same magnesium concentration, 23S RNA comprised a major part of the $\boldsymbol{E}$. coli ribosomal RNA. When $\boldsymbol{R}$. spheroides $\mathrm{RNA}$ was prepared in $10^{-2} \mathrm{M}-\mathrm{MgCl}_{2}$ the presence of trace amounts of RNA corresponding to $E$. coli $23 S$ ribosomal RNA was noted (see Fig. 4c, $d$ ). Close examination of the sedimentation patterns of $R$. spheroides RNA revealed a slight 
deflexion in the profile of the $16 \mathrm{~S}$ boundary, indicating a heterogeneity of the ' $16 \mathrm{~S}$ ' RNA.

Schlieren optics. Characterization of Rhodopseudomonas spheroides RNA by analytical ultracentrifugation and schlieren optics confirmed that the occurrence of $R$. spheroides ' $23 \mathrm{~S}$ ' ribosomal RNA was strictly dependent upon high magnesium concentration (see Figs. 5, 6). In addition, sedimentation analysis with schlieren optics clearly showed the presence of a ribosomal RNA which sedimented less rapidly than did $16 \mathrm{~S}$ RNA. In contrast, identical analyses of Escherichia coli RNA showed that 23S RNA occurred in solutions of low magnesium concentration (see Fig. 5). Furthermore, no particle corresponding to the slowly sedimenting $\boldsymbol{R}$. spheroides ribosomal RNA was observed. We interpret these data to indicate that the basic unit of ribosomal RNA in $R$. spheroides is the $16 \mathrm{~S}$ particle.

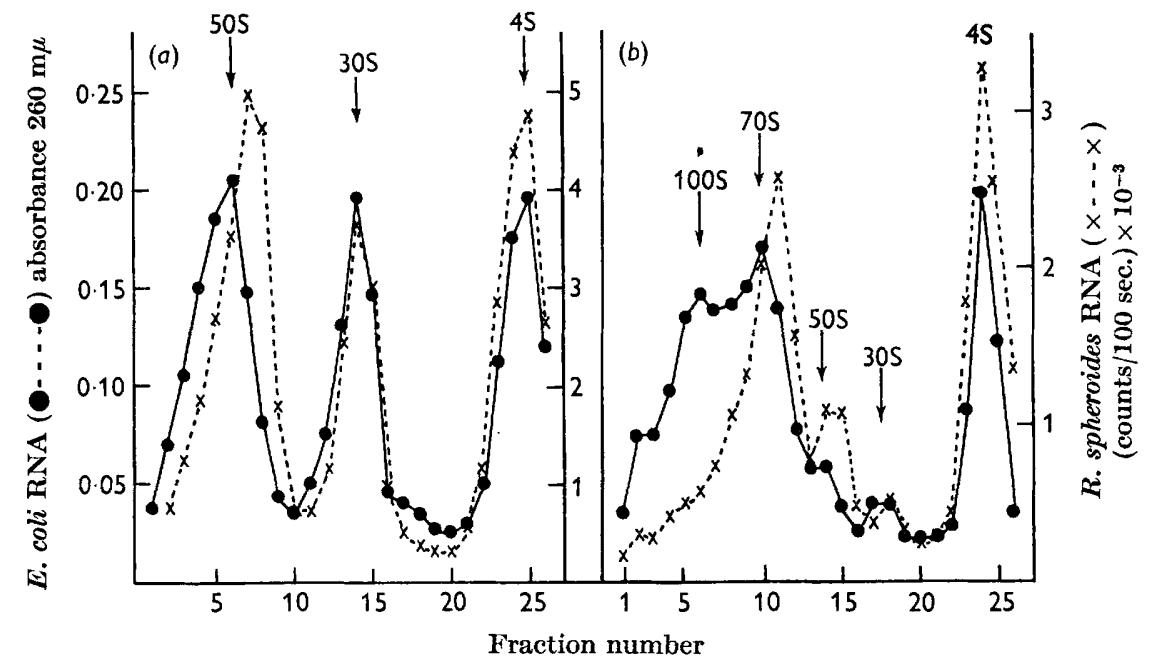

Fig. 2. A portion of the mixture of Escherichia coli and Rhodopseudomonas spheroides ribosomes described in Fig. 1 was divided into two portions. One was dialysed against tris buffer containing $10^{-4} \mathrm{M}-\mathrm{MgCl}_{2}$ and the other against buffer containing $10^{-2} \mathrm{M}-\mathrm{MgCl}_{2}$. Samples $\left(0.2 \mathrm{ml}\right.$.) of the ribosome mixture dialysed against $10^{-4} \mathrm{M}-\mathrm{MgCl}_{2}$ were centrifuged for $2.5 \mathrm{hr}$ through $\mathbf{5 - 2 0} \%$ (w/v) linear sucrose gradient solutions containing $10^{-4} \mathrm{M}^{-\mathrm{MgCl}_{2}}$ (Fig. 2a). Samples of the ribosome mixture dialysed against $10^{-2} \mathrm{M}-\mathrm{MgCl}_{2}$ were centrifuged for $2.5 \mathrm{hr}$ through $15-30 \%$ sucrose gradient solutions containing $10^{-2} \mathrm{M}-\mathrm{MgCl}_{2}$ (Fig. $2 b$ ). Fractions were collected, and their radioactivities and $260 \mathrm{~m} \mu$ extinction were measured.

\section{Ribosomal RNA of other Athiorhodaceae}

Phenol-purified RNA specimens from Rhodospirillum rubrum and the Rhodopseudomonas species $R$. palustris, $R$. gelatinosa, and $R$. capsulata, as well as those of $R$. spheroides strains $\mathrm{L}$ and $\mathrm{L}-81$, were characterized in $10^{-4} \mathrm{M}-\mathrm{MgCl}_{2}$ by analytical ultracentrifugation and the use of u.v. optics. Only $R$. capsulata and the $R$. spheroides strains L and L-81 had the unusual RNA complement characteristic of $R$. spheroides strains Ga and M-25. The other Athiorhodaceae had a ribosomal RNA complement like that of Escherichia coli. Phenol-purified RNA from $R$. capsulata strain 2.3.11 
was further characterized by sucrose density-gradient centrifugation and analytical ultracentrifugation with schlieren optics. Both these methods confirmed that $\boldsymbol{R}$. capsulata had a ribosomal RNA complement like that of $\boldsymbol{R}$. spheroides.

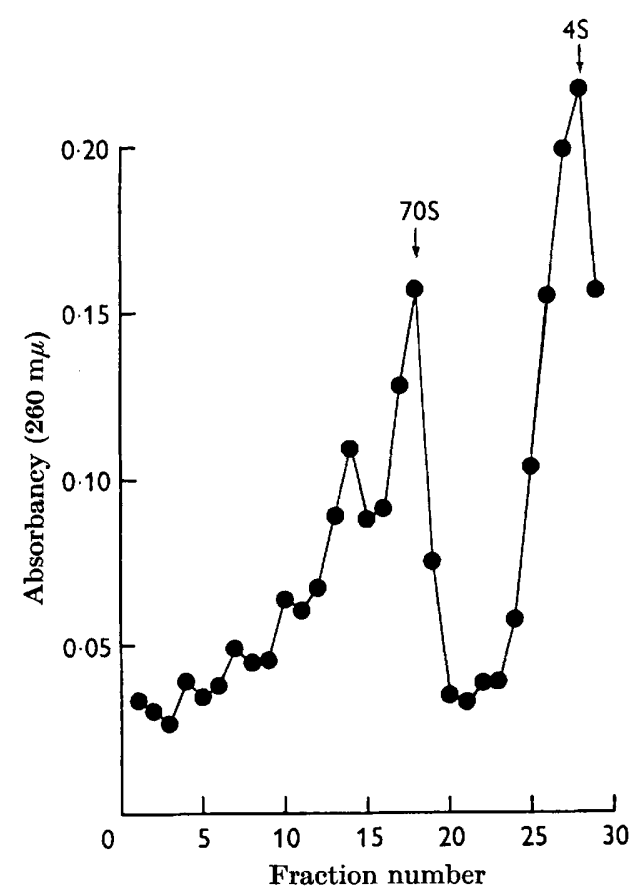

Fig. 3

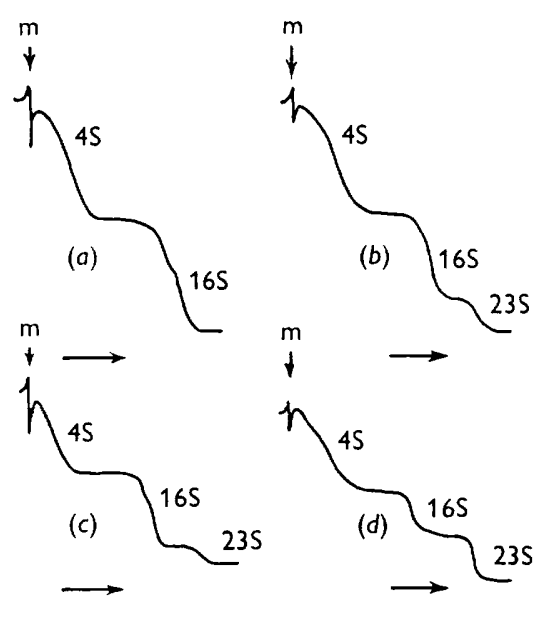

Fig. 4

Fig. 3. An anaerobic culture ( $900 \mathrm{ml}$.) of $R$. spheroides strain $\mathrm{Ga}$ (see Methods) was poured on to $300 \mathrm{~g}$. crushed ice with $2 \cdot 4 \mathrm{ml} . \mathrm{M}-\mathrm{MgCl}_{2}$ and $6 \mathrm{ml} .2 \times 10^{-1} \mathrm{M}-\mathrm{NaN}_{3}$. The organisms were centrifuged, and washed in $5 \times 10^{-3} \mathrm{M}$-tris buffer $(\mathrm{pH} \mathrm{7 \cdot 4})$ containing $2 \times 10^{-3} \mathrm{M}-\mathrm{MgCl}_{2}$ and $10^{-3} \mathrm{M}_{-} \mathrm{NaN}_{3}$. The washed bacteria were treated to obtain a polyribosome extract (see Methods). Portions $(0 \cdot 2 \mathrm{ml}$.) of the extract were applied to $15-30 \%(\mathrm{w} / \mathrm{v})$ linear sucrose gradient solutions containing $2 \times 10^{-3} \mathrm{M}-\mathrm{MgCl}_{2}$. The gradient samples were centrifuged for $90 \mathrm{~min}$. at $38,000 \mathrm{rev} . / \mathrm{min}$. Fractions were collected and their $260 \mathrm{~m} \mu$ extinctions determined.

Fig. 4. Organisms from $600 \mathrm{ml}$. of an anaerobic culture of Rhodopseudomonas spheroides were treated to obtain phenol-purified RNA. Phenol-purified RNA was also prepared from $600 \mathrm{ml}$. of a culture of Escherichia coli. One portion of each RNA sample was dialysed against tris buffer containing $10^{-4} \mathrm{M}^{-\mathrm{MgCl}_{2}}$. Another portion of each sample was dialysed against buffer containing $10^{-2} \mathrm{M}_{-} \mathrm{MgCl}_{2}$. The dialysed samples were diluted in buffers containing the same concentrations of $\mathrm{MgCl}_{2}$, to give final RNA concentrations of about $50 \mu \mathrm{g} . / \mathrm{ml}$. The diluted samples were centrifuged at $50,740 \mathrm{rev} . / \mathrm{min}$. in an analytical ultracentrifuge fitted for u.v. optics. The sedimentation patterns shown were obtained 24 min. after reaching full speed. (a) R. spheroides $\mathrm{RNA}, 10^{-4} \mathrm{M}_{-} \mathrm{MgCl}_{2} ;(b) \mathrm{E}$. coli RNA, $10^{-4} \mathrm{M}-\mathrm{MgCl}_{2}$; (c) R. spheroides $\mathrm{RNA}, 10^{-2} \mathrm{M}_{-} \mathrm{MgCl}_{2} ;($ d $)$ E. coli RNA, $10^{-2}$ $\mathrm{M}-\mathrm{MgCl}_{2}$. The apparent sedimentation coefficients of the RNA components were as follows: $(a), 5 \cdot 5,17 \cdot 5 ;(b), 6 \cdot 6,16 \cdot 3,21 \cdot 3 ;(c), 4 \cdot 7,21 \cdot 8,29 \cdot 6 ;(d) 6 \cdot 8,20 \cdot 6,31 \cdot 4$. The boundary between the solutions and the air space in the centrifuge cells is indicated by $m$. 

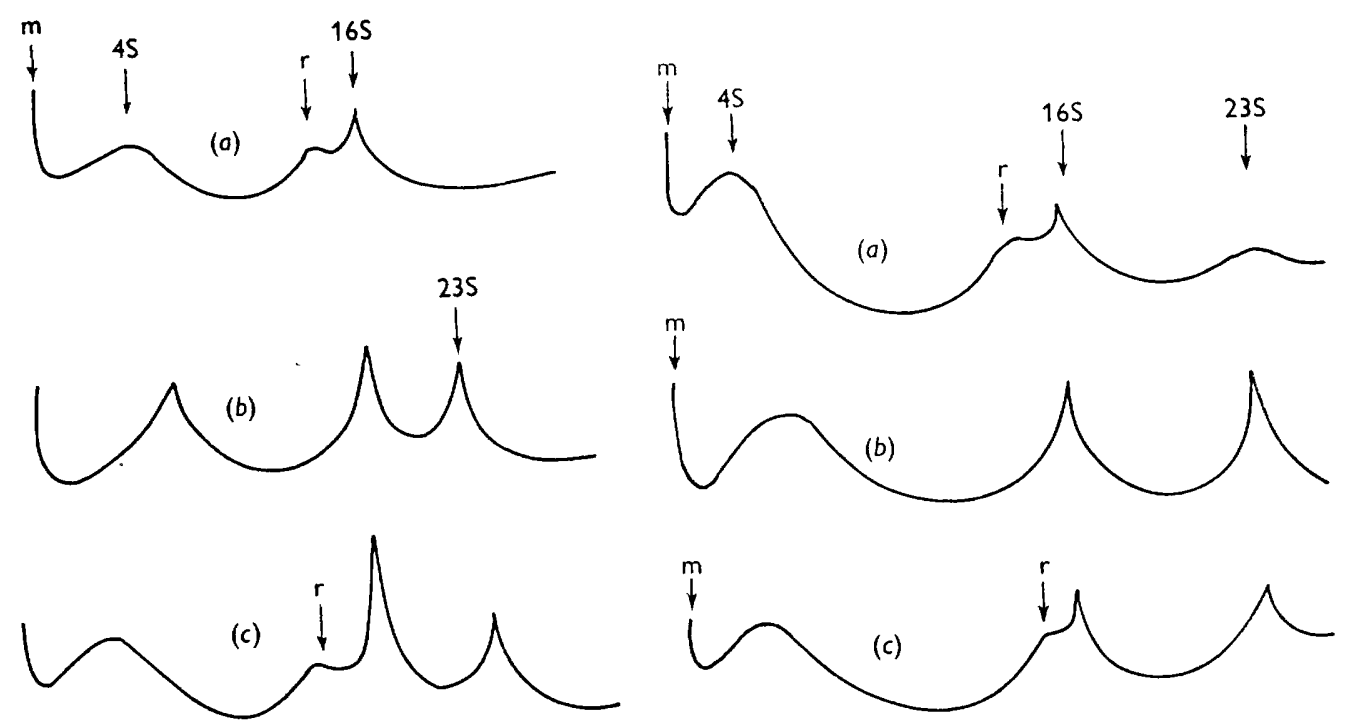

Fig. 5

Fig. 6

Fig. 5. The samples of Rhodopseudomonas spheroides and Escherichia coli used were those described in Fig. 4. Samples which had been dialysed against $10^{-4} \mathbf{M}-\mathbf{M g C l}_{2}$ were diluted in buffer containing the same concentration of $\mathrm{MgCl}_{2}$ to an $\mathrm{RNA}$ concentration of about $1.5 \mathrm{mg} . / \mathrm{ml}$. A mixture of $E$. coli and $\boldsymbol{R}$. spheroides RNA was obtained by mixing equal volumes of the diluted samples. The mixture and the individual samples were each centrifuged at $50,740 \mathrm{rev} . / \mathrm{min}$. in an analytical ultracentrifuge with schlieren optics. The sedimentation patterns shown were obtained $32 \mathrm{~min}$. after attaining full speed. (a) R. spheroides RNA; (b) E. coli RNA; (c) R. spheroides + E. coli RNAs. The apparent sedimentation coefficients of the RNA components were: $(a) 3 \cdot 7,10 \cdot 8,12 \cdot 8 ;(b) 5 \cdot 6$, $12 \cdot 7,17 \cdot 2 ;(c) 3 \cdot 6,11 \cdot 8,14 \cdot 2,18 \cdot 4$. The $R$. spheroides RNA which sedimented between soluble RNA and 16S RNA is indicated by $r$.

Fig. 6. The Rhodopseudomonas spheroides and Escherichia coli RNA samples used were those described in Fig. 4. Samples which had been dialysed against tris buffer containing $10^{-2} \mathrm{M}-\mathrm{MgCl}_{2}$ were diluted in buffer containing the same concentration of $\mathrm{MgCl}_{2}$ to an RNA concentration of about $1.5 \mathrm{mg} . / \mathrm{ml}$. The mixture of $R$. spheroides and $E$. coli RNAs was prepared by mixing equal volumes of each of the diluted samples. The mixture of RNAS and the individual samples were centrifuged at $50,740 \mathrm{rev} \cdot / \mathrm{min}$. The sedimentation patterns shown were obtained 24 min. after attaining full speed. (a) $R$. spheroides RNA; (b) E. coli RNA; (c) R. spheroides $+E$. coli RNAs. The apparent sedimentation coefficients of the RNA components were: $(a) 3 \cdot 2,18 \cdot 5,19 \cdot 6,29 \cdot 6 ;(b) 6 \cdot 5,19 \cdot 5,29 \cdot 0 ;(c) 4 \cdot 0$, $17 \cdot 0,20 \cdot 5,29 \cdot 0$. The $R$. spheroides RNA which sedimented between soluble RNA and 16S RNA is indicated by $\mathrm{r}$.

\section{DISCUSSION}

The results presented here strongly suggest that Rhodopseudomonas spheroides is able to form its ribosomes from a $16 \mathrm{~S}$ ribosomal RNA unit. Studies of other bacteria which have suggested that two distinct ribosomal RNAs are necessary to form the usual complement of their ribosomes should be re-examined in the light of the present findings. The work of Petermann \& Pavlovec (1963) indicated that there is conversion between the $18 \mathrm{~S}$ and $28 \mathrm{~S}$ ribosomal RNA of rat liver. This suggests that the difference between $R$. spheroides ribosomal RNA and that of other microorganisms may be a difference in the ability of the respective $16 \mathrm{~S}$ units to dimerize to $23 \mathrm{~S}$ units. On the other hand, the RNA-DNA hybridization experiments of 
Yankofsky \& Spiegelman (1963) imply that 23S RNA is not a dimer of 16S RNA, but a distinct unit formed at a different site on the bacterial genome. This view is supported by data which show differences in the base sequences of the RNA from $30 \mathrm{~S}$ and $50 \mathrm{~S}$ ribosomes (Aronson, 1962, 1963).

The present observations that Rhodopseudomonas spheroides $70 \mathrm{~S}$ ribosomes did not dimerize with an excess of Escherichia coli $70 \mathrm{~S}$ particles to form $100 \mathrm{~S}$ units, and that the $50 \mathrm{~S}$ and $70 \mathrm{~S}$ ribosomes of $\boldsymbol{R}$. spheroides sedimented behind corresponding $\boldsymbol{E}$. coli particles suggest that the $R$. spheroides $50 \mathrm{~S}$ ribosome lacks some structural element which is present in the $\boldsymbol{E}$. coli $50 \mathrm{~S}$ particle. For several reasons it is attractive to speculate that such an element exists, and that it is a low molecular weight RNA. It is consistent with hybridization data, base sequence data, and data which suggest interconversion of $16 \mathrm{~S}$ and $23 \mathrm{~S}$ RNA to postulate that there are two classes of 50S ribosomes. One, represented by the $50 \mathrm{~S}$ ribosome of $R$. spheroides, would be built from two $16 \mathrm{~S}$ ribosomal RNA units. The other, represented by the $E$. coli $50 \mathrm{~S}$ ribosome, might be derived from a 23S ribosomal RNA which consisted of two 16S units associated with an additional piece of RNA not present in the $R$. spheroides ribosome. This hypothesis would allow for the interconversion of $16 \mathrm{~S}$ and $23 \mathrm{~S}$ RNAs and for the exclusion of 16S RNA from hybridization sites available to 23S RNA.

I cannot offer any explanation for the presence in preparations of Rhodopseudomonas spheroides RNA of significant amounts of ribosomal RNA which sedimented more slowly than does 16S RNA. However, Yankofsky \& Spiegelman (1963) observed a similar heterogeneity upon salt-gradient elution of Bacillus megaterium I6S RNA from methylated serum albumin columns.

I am indebted to Dr June Lascelles for her advice and encouragement throughout this work, and wish to thank Dr K. Burton and Professor H. Harris for helpful suggestions and criticisms. During this project the author held a post-doctoral fellowship from the U.S. Public Health Service. The work was also aided by grants to the Department from the Rockefeller Foundation and the United States Department of Health, Education, and Welfare.

\section{REFERENCES}

Aronson, A. I. (1962). Sequence differences between ribonucleic acids isolated from $30 S$ and $50 \mathrm{~S}$ ribosomes. J. mol. Biol. 5, 453.

Aronson, A. I. (1963). Nucleotide sequence differences among ribosomal ribonucleic acid fractions and soluble ribonucleic acid fractions from various bacterial species. Biochim. biophys. Acta, 72, 176.

Aronson, A. I. \& McCarthy, B. J. (1961). Studies of $E$. coli ribosomal RNA and its degradation products. Biophys. J. 1, 215.

Britten, R. J. \& Roberts, R. B. (1960). High resolution gradient sedimentation analysis. Science, 131, 32.

KurLand, C. G. (1960). Molecular characterization of ribonucleic acid from Escherichia coli ribosomes. J. mol. Biol. $2,83$.

LASCELlES, J. (1959). Adaptation to form bacteriochlorophyll in Rhodopseudomonas spheroides: changes in activity of enzymes concerned in pyrrole synthesis. Biochem. $J$. $72,508$.

Lowry, O. H., Rosebrough, N. J., Farn, A. L. \& Randall, R. J. (1951). Protein measurement with the Folin phenol reagent. J. biol. Chem. 193, 265. 
Petermann, M. L. \& Pavlovec, A. (1963). Studies on ribonucleic acid from rat liver ribosomes. J. biol. Chem. 238, 3717.

Schlessinger, D. (1963). Protein synthesis by polyribosomes on protoplast membranes of B. megaterium. J. mol. Biol. 7, 569 .

SchneIDER, W. C. (1945). Phosphorus compounds in animal tissues. 1. Extraction and estimation of desoxypentose nucleic acid and of pentose nucleic acid. J. biol. Chem. $161,293$.

Schramm, G. \& Grerer, A. (1956). Infectivity of ribonucleic acid from tobacco mosaic virus. Nature, Lond., 177, 702.

SPAHR, P. F. \& Tissieres, A. (1959). Nucleotide composition of ribonucleoprotein particles from Escherichia coli. J. mol. Biol. 1, 237.

YANkofsky, S. A. \& Spiegelman, S. (1963). Distinct cistrons for the two ribosomal RNA components. Proc. natn. Acad. Sci., U.S.A. 49, 539. 